\title{
3 Research Soure \\ Pesticide Use In Vegetable Production In Rural Uganda - A Case Study of Kabale District, South Western Uganda
}

\section{Hannington Ngabirano}

Kabale University Faculty of Science; Mbarara University of Science and technology

Grace Birungi ( $\sim$ gbirungi@must.ac.ug )

Mbarara University of Science and Technology Faculty of Science https://orcid.org/0000-0002-8520$017 X$

\section{Data Article}

Keywords: Vegetables, Pesticides, Pesticide Practices, Kabale District, Uganda

Posted Date: July 9th, 2020

DOI: https://doi.org/10.21203/rs.3.rs-40431/v1

License: (c) (i) This work is licensed under a Creative Commons Attribution 4.0 International License.

Read Full License 


\section{Abstract}

A study to investigate commonly grown vegetables, commonly used pesticides, and pesticide use practices was conducted in Kabale District, in south-western Uganda. This is because indiscriminate pesticide use and poor application practices can leave pesticide residues in food rendering it unsafe for consumption. The study revealed extensive pesticide application in Brassica oleracea; var. capitata (cabbage), Brassica oleracea; var. botrytis (cauliflower), Solanum lycopersicum, (tomato) and Beta vulgaris (beet root). Information obtained using interviews revealed that $16.5 \%$ traders sell pesticides and $70 \%$ farmers spray pesticides on vegetables. Only $18 \%$ of farmers could interpret instructions correctly on a given pesticide container label. All farmers (100\%) had never attended any pesticide use training. Cypermethrin, dimethoate, dichlorvos, metalaxyl, profenofos, malathion and mancozeb were common pesticides used in spraying vegetables however $42 \%$ of the farmers mixed different pesticides for use. Limited knowledge about pesticide application, inability to interpret instructions, non-observation of waiting period before harvesting, mixing pesticides and lack of training on pesticide use for farmers are potential risks to food safety. There is need to address knowledge gaps on safer pesticide application in order to attain safe agricultural productivity for sustainable food security, human health and community development in Kabale District, Uganda.

\subsection{Introduction}

Rapid human population growth has increased food demand worldwide (Tilman et al. 2011, Popp et al. 2013, Maksymiv 2015, Gill and Garg 2014, Jallow et al. 2017, Majeed 2018) which has triggered agricultural intensification (Majeed 2018) yet pests affect crop yields to a great extent (Zanella et al. 2012, Munawar and Hameed 2013); they destroy 30-48\% of world's food yields every year; for instance, in 1987 one third of the potential world crop harvest was lost to pests (Tano 2011). Crop yield losses are a food security threat and pests continue to affect crop yields (Munawar and Hameed 2013). To reduce on food loss, pesticide use has been intensified; however, indiscriminate pesticide use can harm humans and the environment (Majeed 2018). Also, haphazard pesticide application in food crops may compromise food quality, affect prices especially in international food markets, lead to complete refusal due to poor quality products as a result of pesticide contamination. Higher amounts of mixed agrochemicals in food stuffs may result from indiscriminate pesticide use and hence such practices call for better pesticide use regulation.

According to Knight and Norton (1989), improper pesticide-use could result in water pollution and food contamination, endangering human health and non-target species. Improving pesticide practices and reduced pesticide use is beneficial to everyone and the environment (Bon et al. 2014). Alternative nonchemical pest management methods include, among others, biological control and mechanical control (nets and traps), which have shown positive results in various studies from African countries (Bon et al. 2014, Vidogbena et al. 2015). However, a knowledge gap about their use and efficacy still exists especially in small scale farming for example in low scale vegetable production. 
Vegetables constitute a major food component and source of income in many parts of the world; they produce higher returns per unit area and time (Ragini 2015) and are consumed as side dish (Grubben and Denton 2004). Vegetable consumption ensures adequate dietary supply of vitamins, minerals, water, and dietary fibre (Sinyangwe et al. 2016). An adult is recommended to consume 400 grams of vegetables daily for a healthy life (Smith and Eyzaguirre 2007, JICA 2016). To cope with the increasing vegetable demand, and reduction in crop loss, pesticides are used especially in vegetable growing to increase productivity, protect nutritional integrity, facilitate storage to ensure year-round supplies, and provide attractive vegetable products (Chow 2016).

Different pesticides can be used depending on the plants and pests involved (Schwinn 1988, Özkara et al. 2016); they are generally described as: insecticides (organophosphates, organocarbamates, organochlorines, pyrethrins and pyrethroids) and fungicides (thiocarbamates, dithiocarbamates) (Fouche et al. 2000, Fait et al. 2001, Fenik et al. 2011). There is widespread use of pesticides in most developing countries (Ohayo - Mitoko 1997) where some farmers apply them indiscriminately which raises concern over food safety (Perez et al. 2015) and health consequences of excessive pesticide use on consumers' safety and the environment in general which require country governments to revise pesticide residue standards (Okello and Swinton 2011).

A study carried out in Bangladesh on use of pesticide and its impact on health of farmers showed that among the three pesticide groups: organophosphate, organocarbamate and synthetic pyrethroids used in the country, synthetic pyrethroids caused the least harm. Farmers did not always follow the appropriate methods of pesticide use and the waiting period to harvest vegetables (Miah et al. 2014). Pesticide use malpractices are a food safety challenge and the limited information on pesticide use practices in subSaharan Africa motivated this study.

Small-scale farmers in several African countries used insufficient personal protection equipment and unsafe pesticide handling practices (Naidoo et al. 2010). Poor pesticide practices were attributed to lack of knowledge about side effects and failure to follow instructions on pesticide usage (Bon et al. 2014). Pesticide application malpractices included use of unregistered pesticides, inappropriate dosage, lack of adherence to pre-harvest interval, use of banned pesticides, inappropriate use of pesticides such as inappropriate pesticide/crop combination and the use of a mixture of different pesticides in a single spray (Ngowi et al. 2007, Marčić et al. 2011, Nonga et al. 2011, WHO and IPCS 2010). There is insufficient data on pesticide use practices in Uganda hence a need for this study.

A study conducted by Oesterlund et al. (2014) revealed the extent of pesticide use by small-scale farmers in Uganda and examined the knowledge, practice and impact of protective measures and the storage of pesticides and attitudes. The study showed that the most frequently used pesticides belonged to World Health Organization (WHO) class II. Farmers had limited knowledge about pesticide toxicity, did not use appropriate personal protection equipment or good hygiene when handling pesticides, it was important to assess whether the status had changed since then. 
Misuse of pesticides was observed in Mindu dam, Tanzania (Mdegela et al. 2013) where majority of the farmers re-packed pesticides locally in small quantities in improvised containers without safety instructions for use and handling. Mixing pesticides in knapsack sprayers was also a common practice. This creates a potential risk of the pesticide residues in the crops which can affect food quality and eventually consumer health. There are reports of inappropriate dosages and application rates of pesticides in vegetable farming for instance, a study in Mang'ola District, Tanzania reported that farmers apply pesticides on vegetables at over-dosage levels (Mhauka 2014). Other studies in the Manyara basin and Arumeru District, country showed that farmers applied pesticides on vegetables on a routine basis as a means of protection even though no pest had been observed on the plants (Ngowi et al. 2007, Nonga et al. 2011). This can result in unnecessary production costs and/or unacceptable pesticide residues in the vegetables.

The attention of populations in sub-Saharan Africa (SSA) on vegetables as vital dietary components reinforces the significant roles that leafy vegetables have long held as important components in African diets; they are indispensable ingredients of soups or sauces that accompany carbohydrate staples (Chweya and Eyzaguirre (Eds.) (1999). An average of $10 \%$ of the food budget is spent on fruits and vegetables in various African countries (Joosten et al. 2015).

Vegetables grown across Africa include bottle gourd (Legenaria vulgaris), cabbage (Brassica oleracea var. capitata), cauliflower (Brassica oleracea), carrot (Daucus carota), fluted pumpkin (Telfairia occidentalis), potato (Solanum tuberosum), egg-plant (Solanum aethiopicum), spinach (Spinacia oleracea), sweet pepper (Capsicum annum), water leaf (Talinum triangulare), tomato (Lycopersicon esculentum), and bitter leaf (Vernonia amygdalina). Others include Celosia argentea, amaranths, Abelmoschus esculentus, Capsicum spp. Daucus carota, Allium cepa, Alium sativum, Musa spp, Moringa oleifera, Zathoxylum zanthoxyloides, Telfairia occidentalis, Talinum traingulare, Venonia amygdalina, Lecaniodisus capaniodes, Corchorus olitorius, Piper guninensis, Tamarindus indica, Vigna unguiculata, Basella alba, Crassocepholum, rubens, Cassia occidentalis, Amaranthus palmeri, Bidens pilosa, Urticadiocia, Phaseolus vulgaris, Pisum sativum, Solanum scrabrum, Crotalaria ochroleuca, Vigna unguiculata, Cynara scolymus, Cynara cardunculus, Allium porum, Raphanus sativus, Apium graveolens, Cucumis sativus, Citrullus lanatus, Asparagus officinalis (Ogwu et al. 2016).

Commonly used pesticides in vegetables worldwide include dichlorvos, phorate, cypermethrin, diazinon, fenitrothion, malathion, parathion, profenofos, ethion, acephate, aldrin, captan, chlorpyrifos, dieldrin, disulfoton, endosulfan, fenthion, methoxychlor, parathion-methyl, methamidophos, Bitertanol, carbendazim, flusilazole, hexythiazox, imidacloprid, methidathion, methiocarb, pyriproxyfen and trichlorfon, cyromazine, melamine, thiabendazole, iprodione, vinclozolin, azinphos-methyl, dimethoate, Isofenphos-methyl, isocarbophos, phosalone, phosmet, phosphamidone, pretilachlor, propoxur, pymetrozine, simazine, terbuthylazine, terrazole, thifluzamide, parathion-ethyl, and dicarboxamide, chlorpyrifos-methyl organophosphate, metalaxyl, phenylamide, malathion organophosphate, fenthion organophosphate, phosmet organophosphate, monocrotophos, omethoate, oxydemeton-methyl, 
vamidothion, iprodione, Isopropoxyphenol, naphthol, carbofuran, propham, propoxur, carbaryl, aldicarb, sulfoxide, methomyl, phenanthrene, 4-nitrophenol (Fenik et al. 2011).

Indiscriminate pesticide use in food crops may leave pesticide residues in food beyond concentrations considered safe for consumption (Miah et al. 2014, Okonya and Kroschel 2015, Jallow et al. 2017). According to EUs Pesticide Action Network, (2008), 350 different pesticides were detected in food produced in the EU. More than $5 \%$ of food products contained pesticides at levels exceeding the EUs maximum permitted level (MPL) (Fenik et al. 2011); there is limited information on the status of food produced in Uganda yet occurrence of pesticide residues in food is a threat to food security due to the health risks associated with consumption of tainted food (Miah et al. 2014).

While information on the most commonly used pesticides Uganda is scarce most farming is done on small-scale farmers where farmers have less than a few acres of land per household and often farm without appropriate means or knowledge to use pesticides (Salameh et al. 2004, Jors et al. 2006). In the absence of appropriate handling of pesticides, not only the health of farmers, but also the health of their families is at risk (Macfarlane et al. 2008, Sam et al. 2008, Williamson et al. 2008). This study therefore was aimed at investigating the commonly grown vegetables, the common pesticides used in vegetables spraying and the knowledge of farmers on pesticide application practices in Kabale District, Uganda.

\subsection{Materials And Methods}

\subsection{Study Area Description}

Kabale District a highland district of Uganda in the South West of the Republic of Uganda. It borders with districts of Rubanda to the West, Rukiga in the North and East and the Republic of Rwanda to the South (Fig. 1). Kabale district is $402 \mathrm{~km}$ from the capital city Kampala, lying between $29^{\circ} 45^{\prime}$ and $30^{\circ} 15^{\prime}$ East longitude and $1^{\circ} 00^{\prime}$ and $1^{\circ} 29^{\prime}$ South of latitude (Langan and Farmer 2014). The district has an estimated population of 212,506 . Out of these, only $49,667(23 \%)$ stay in the municipality and the remaining 162,839 (77\%) stay in the rural area. The people are predominantly from Bakiga tribe and a few Batwa (pigmies), Banyarwanda and Bahororo tribal clans. It is one of the most populated districts with projected population density approximated to be at 358 people per $\mathrm{Km}^{2}$ (Uganda Bureau of Statistics 2014). Kabale Municipality is comprised of Kabale Northern Division, Kabale Central Division and Kabale Southern Division and the three sub counties (Kaharo, Kyanamira and Kamuganguzi) were selected for the study (see Fig. 1).

\subsection{Materials}

The study population was composed of pesticide traders and vegetable farmers. The number of vegetable farmers interviewed out of total population $(12,693)$ in three sub-counties of Kaharo, Kyanamira and Kyanamira and the number of traders interviewed out of total population (416) operating from Kabale municipality were determined using Krejcie and Morgan's Table (Krejcie ad Morgan 1970). 
Standardised interview questions were designed for both traders and farmers to ensure homogeneity in responses, that is, traders and farmers were asked predetermined questions related to pesticide use in vegetables grown in the district in the same order and scoring system.

\subsection{Methods}

This study was designed as a cross-sectional survey on vegetables grown; pesticides used in the vegetables and associated pesticide use practices in Kabale District, Uganda. The study was conducted using face-to-face interviews with traders and farmers. Data was collected basing on responses to the interview questions which were designed in English, a language understood by majority of the traders but some translation was done to Rukiga language for farmers who did not know English. The survey was conducted in April, 2017. In the survey, traders operating from central market in Kabale Municipality and vegetable farmers in Kaharo, Kyanamira and Kyanamira sub-counties were interviewed.

Krejcie and Morgan's Table (Krejcie ad Morgan 1970) was used to determine the number of respondents. The active ingredients present in the pesticides were determined by reading their names and quantities on the pesticide container labels. Respondents were interviewed on commonly grown vegetables, pesticides sprayed in the vegatables, on the importance of pesticide use in vegetables, known adverse effects of pesticides, ability to interpret instructions on pesticides container labels, waiting periods after pesticide application, mixing of pesticides and trainings on pesticide use attended.

\subsection{Results And Discussion}

\subsection{Number of Participants in the Survey}

The number of traders interviewed during the survey as per Krejcie and Morgan's Table (Krejcie ad Morgan 1970) was 200 traders out of the total of 416 traders. Similarly, the number of vegetable farmers interviewed was determined to be 400 farmers out of 12,693 therefore 200 traders and four hundred (400) farmers selected at random were interviewed.

\subsection{Commonly Grown and Pesticide Sprayed Vegetables in Kabale District, Uganda}

The commonly sprayed vegetables in the District were as indicated in Table 1. 
Table 1

Pesticide Sprayed Vegetables

\begin{tabular}{|ll|}
\hline Types of vegetables & Frequency \\
\hline Tomatoes ( Solanum lycopersicum) & 180 \\
\hline Cabbages (Brassica oleracea; var. capitata) & 144 \\
\hline Cauliflower (Brassica oleracea; var. botrytis) & 84 \\
\hline Beet root (Beta vulgaris) & 48 \\
\hline Carrots (Daucus carota) & 30 \\
\hline Green paper (Piper nigrum L) & 30 \\
\hline Egg plants (Solanum melongena) & 18 \\
\hline African egg plants ( Solanum aethiopicum) & 18 \\
\hline Onions (Allium cepa) & 12 \\
\hline
\end{tabular}

As shown in Table 1 tomatoes, cabbages, cauliflower, and beetroot had the highest frequency. The findings on the extent of vegetable growing in Kabale District can be attributed to fertile soils, land shortage, quick source of income and general lack of major cash crops (Carswell 2003 and Personal observation). Four vegetable types (cabbage, cauliflower, tomato and beetroot) out of the nine types of the commonly grown and sprayed vegetables are of high demand for home consumption and sale locally or export. Community based organisations were also found to engage in cabbage growing for income generation (Uganda Farmers Guide 2019).

\subsection{Common Pesticides sold and their Active Ingredients}

The results obtained revealed that 33 traders (16.5\%) sold pesticides in their shops in Kabale District, Uganda. The common pesticides used in vegetables in Kabale District belonged to two categories namely: insecticides (pyrethroids, organochlorines, organophosphates and carbamates) (53\%) and fungicides (47\%) shown in Table 2. The findings of the study were in agreement with the results obtained by Ngowi et al. 2007. While pesticides had different trade names, active ingredients were similar, and the most common were dichlorvos, metalaxyl, dimethoate, profenofos, malathion, mancozeb and cypermethrin. 
Table 2

Pesticide Types Present in Shops and their Active Ingredients

\begin{tabular}{|c|c|c|c|}
\hline Class of pesticide & Trade names & $\begin{array}{l}\text { Active ingredients (a.i) and their amounts } \\
\mathrm{Kg}^{-1}\end{array}$ & Total FrEq. \\
\hline \multirow[t]{8}{*}{$\begin{array}{l}\text { Fungicides } \\
\text { (Systemic) }\end{array}$} & Ridomil & ${ }_{1}^{\text {Mancozeb } 640 \mathrm{~g} \cdot \mathrm{Kg}^{-1}+\text { Metalaxyl } 40 \mathrm{~g} \cdot \mathrm{Kg}^{-}}$ & Fungicides \\
\hline & Eureka & ${ }_{1}^{\text {Mancozeb } 640 \mathrm{~g} \cdot \mathrm{Kg}^{-1}+\text { Metalaxyl } 40 \mathrm{~g} \cdot \mathrm{Kg}^{-}}$ & \multirow{15}{*}{352} \\
\hline & Victory & ${ }_{1}^{\text {Mancozeb } 640 \mathrm{~g} \cdot \mathrm{Kg}^{-1}+\text { Metalaxyl } 40 \mathrm{~g} \cdot \mathrm{Kg}^{-}}$ & \\
\hline & ${ }_{\text {TATA }}$ Master & $\underset{1}{\text { Mancozeb } 640 \mathrm{~g} \cdot \mathrm{Kg}^{-1}+\text { Metalaxyl } 40 \mathrm{~g} \cdot \mathrm{Kg}^{-}}$ & \\
\hline & Kingmill & ${ }_{1}^{\text {Mancozeb } 640 \mathrm{~g} \cdot \mathrm{Kg}^{-1}+\text { Metalaxyl } 40 \mathrm{~g} \cdot \mathrm{Kg}^{-}}$ & \\
\hline & Milraz & $\underset{1}{\text { Mancozeb } 640 \mathrm{~g} \cdot \mathrm{Kg}^{-1}+\text { Metalaxyl } 40 \mathrm{~g} \cdot \mathrm{Kg}^{-}}$ & \\
\hline & Osho Master & 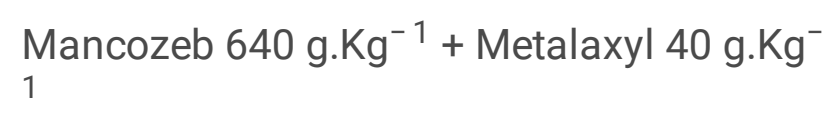 & \\
\hline & $\begin{array}{l}\text { Osho } \\
\text { mistress }\end{array}$ & $\begin{array}{l}\text { Mancozeb } 640 \mathrm{~g} \cdot \mathrm{Kg}^{-1}+\text { Cymoxanil } \\
80 \mathrm{~g} \cdot \mathrm{Kg}^{-1}\end{array}$ & \\
\hline \multirow{8}{*}{$\begin{array}{l}\text { Fungicides } \\
\text { (Non-systemic) }\end{array}$} & Unizeb & Mancozeb 80\% & \\
\hline & & & \\
\hline & Mancodoze & Mancozeb 80\% & \\
\hline & Mancozeb & Mancozeb 80\% & \\
\hline & Sicozeb & Mancozeb 80\% & \\
\hline & Tridex & Mancozeb 80\% & \\
\hline & Mancoera & Mancozeb 80\% & \\
\hline & Oshothane & Mancozeb 80\% & \\
\hline \multirow[t]{3}{*}{$\begin{array}{l}\text { Insecticides } \\
\text { (systemic) }\end{array}$} & Uthoate & Dimethoate & \multirow{3}{*}{$\begin{array}{l}\text { Insecticides } \\
400\end{array}$} \\
\hline & Tagfor & Dimethoate & \\
\hline & Sicothoate & Dimethoate & \\
\hline
\end{tabular}




\begin{tabular}{|lll|}
\hline Class of pesticide & Trade names & $\begin{array}{l}\text { Active ingredients (a.i) and their amounts } \\
\mathrm{Kg}^{-1}\end{array}$ \\
\hline $\begin{array}{l}\text { Insecticides } \\
\text { (non-systemic) }\end{array}$ & Rocket & Cypermethrin $4 \%+$ profenofos $40 \%$ \\
\hline & Supacyper & Cypermethrin $5 \%$ \\
& Cyperlacer & Cypermethrin $5 \%$ \\
\hline Uchlorvos & Uchlorvos & Uchlorvos $100 \%$ \\
\hline Malathion & Malathion & Malathion $50 \%$ \\
\hline $\begin{array}{l}\text { 3.4 Knowledge of Effects of Pesticides and Prevention of } \\
\text { exposure }\end{array}$
\end{tabular}

Farmers' responded that in addition to vector control, pesticides improved productivity in vegetable growing $(90 \%)$, could also affect food quality $(8 \%)$, contaminate non-target vegetation $(2 \%)$ and surface water $(6 \%)$. All traders and farmers were aware of the harmful effects of exposure to pesticides on human health (see Table 3). Excess pesticide spraying can contribute to the accumulation of pesticide residues in food which is associated with variety of human health hazards, including damage to central and peripheral nervous systems, cancer, allergies and hypersensitivities, reproductive disorders, and disruption of the immune system (Grewal et al. 2017). 
Table 3

Responses on the possible Adverse Effects of Pesticides on Human Heath

\begin{tabular}{|c|c|c|}
\hline \multicolumn{3}{|l|}{ Traders' Responses } \\
\hline Signs of the Effects & Frequency & Percentage \\
\hline Cancer & 33 & 100 \\
\hline Stomach cramps (pains) & 31 & 94 \\
\hline Brain damage & 31 & 94 \\
\hline Diarrhoea & 30 & 91 \\
\hline Skin irritation & 29 & 88 \\
\hline Infertility & 28 & 85 \\
\hline Allergies & 28 & 85 \\
\hline Weakness & 27 & 82 \\
\hline Headache & 26 & 79 \\
\hline Dizziness & 24 & 73 \\
\hline Vomiting & 24 & 73 \\
\hline Birth defects & 20 & 61 \\
\hline Difficult breathing & 18 & 55 \\
\hline Thirst & 15 & 45 \\
\hline Organ failure & 13 & 39 \\
\hline Confusion & 12 & 36 \\
\hline obesity & 11 & 33 \\
\hline Nausea & 10 & 30 \\
\hline Chills & 9 & 27 \\
\hline Autism & 7 & 21 \\
\hline Excessive sweating & 4 & 12 \\
\hline Chest pains & 3 & 9 \\
\hline Diabetes & 3 & 9 \\
\hline Loss of sensation & 1 & 3 \\
\hline Endocrine complications & 1 & 3 \\
\hline
\end{tabular}




\begin{tabular}{|lll|}
\hline Traders' Responses & & \\
\hline Farmers' responses & & \\
\hline Signs of the effects & Frequency & Percentage \\
\hline Cancer & 328 & 82 \\
\hline Allergies & 176 & 44 \\
\hline Learning problems & 160 & 40 \\
\hline Nervous system problems & 144 & 36 \\
\hline Weakened immune system & 112 & 28 \\
\hline
\end{tabular}

Prevention measures against effects of pesticides were generally well known to both pesticide traders and vegetable growers were as shown in Table 4. 
Table 4

Responses on preventive measures of pesticides' effects on human health

\section{Traders' responses on preventive measures of pesticides' effects on human health}

\section{Preventive measures}

Wash the vegetables before eating them

Training farmers on how to apply pesticides

Respecting actual timelines for harvesting after spraying

Grow vegetables for domestic consumption

Buy unsprayed or organic products
Frequency Percentage

46

42

33

3

2

4

92

84

66

6

4

\section{Farmers' responses on preventive measures of pesticides' effects on human health}

Concerned food quality and government agencies should establish pesticide residue monitoring centres at district level

Farmers should be trained on how to apply pesticides and make them understand their effects on human life

Farmers should follow actual timelines for harvesting after spraying

Farmers should use proper pesticide concentrations as instructed by the manufacturers

Wash sprayed food before consumption

Grow fruits and vegetables for home consumption

Buy unsprayed or organic vegetables or fruits

Dry the vegetables before consumption

Peel the outer layer

Identify vegetables with the highest pesticide load and avoid them th
3

2

3

1

3

6

2

4

5

2

1

3

10

7

10

21

7

14

17

7

3

The impact of pesticide residues can be minimised by preventive measures such as rational use of pesticides, washing and proper processing of food products, practicing organic farming, use of natural pesticides and bio-pesticides, and strict implementation and amendment of pesticide-related laws (Grewal et al. 2017).

\subsection{Pesticide Use Practices}

Farmers' responses showed that $42 \%$ mix different pesticides before use and $58 \%$ do not mix pesticides. Some farmers mix two or more pesticides in the same spray with the aim of increasing efficacy. Similar practices were reported in Tanzania (Ngowi et al. 2007, Mhauka 2014) although this is not recommended. 
Mixing of pesticides in the same spray tank can result into synergistic or antagonistic effects which are not well investigated. Pesticide mixtures can affect plant health, reduce yield and result in multiple pesticide residues in vegetables (Ngowi et al. 2007, Moshi and Matoju 2017) which can cause various health hazards in humans as well as high production costs. Furthermore codes of best practices prohibit use of a mixture of pesticides unless advised by the manufacturer or inherent in the formulation (Ngowi et al. 2016, Lekei et al. 2014).

Another major observation was that not all farmers could read and interpret instructions on pesticide containers. About $82 \%$ could not interpret instructions on labels of pesticide containers and only $18 \%$ could easily follow instructions given on pesticide containers. There is a need to address this challenge to allow for proper pesticide use in vegetables in Kabale District to avoid wrong reconstitution and application practices

Observation of post spray waiting periods was haphazard; about $17.5 \%$ of the farmers harvested vegetables after 1 hour of pesticide spraying, 21\% of the farmers after 3 hours, and $32.5 \%$ after 6 hours. $41.8 \%$ waited after 1 day of pesticide spraying to harvest vegetables, $4 \%$ waited 2 days while only $2 \%$ of the farmers harvested vegetables after 3 days of pesticide spraying. Longer waiting period may allow pesticide degradation to less toxic levels. Non adherence to the pre-harvesting period waiting periods can be associated with accumulation of pesticide residues in vegetables. Therefore it is important to observe an adequate waiting period, moreover, many pesticides are systemic, which thus they penetrate into the fruit and vegetable itself and cannot be washed off (Miah et al. 2014). This may lead to pesticide residue above acceptable concentrations in the vegetables or fruit sprayed with pesticides.

All the farmers interviewed had never attended formal training on pesticide use and these findings were in similar to those obtained by Pujara and khanal (2002), in their study among vegetable growers of Jaishidihi sub-catchment in Nepal. A low level of education and limited professional pesticide application training may lead to poor pesticide handling practices and contribute to increased risk of human exposure through occupation exposure and food consumption (Ngowi et al. 2007, Nonga et al. 2011, Marčić et al. 2011, WHO and IPCS 2010, Mdegela et al. 2013).

\subsection{Conclusion}

In Kabale District, Uganda, cabbages, cauliflower, tomatoes and beetroot were commonly grown and sprayed with cypermethrin, mancozeb, profenofos, malathion, metalaxyl dichlorvos and dimethoate, individually or in mixtures. Poor pesticide use practices were observed and this could be attributed to the lack training on pesticide use implying that there is need for a comprehensive program to train farmers on pest control.

While traders and farmers had limited information about the various ingredients present in pesticides; they expressed concern about adverse effects on human health associated with pesticide exposure. Preventive measures such as washing vegetables before consumption, growing vegetables for home consumption organically without spraying and buying unsprayed vegetables were well known. 
While majority of the farmers ( $84 \%$ ) stated that pesticide use as the best option to control pests in vegetables, only $18 \%$ of the farmers could correctly interpret instructions on labels provided on pesticide containers. Some farmers (42\%) mix pesticides to use in vegetables, adherence to post sprat waiting periods was haphazard and inadequate in many cases. Thus, there is need for broad based farmers' trainings on pesticide use in Kabale District, regional and countrywide to reduce risk associated with pesticide use malpractices.

\section{Declarations}

Availability of data and materials: All data and materials for publication are provided within the manuscript

Competing interests: There are no competing interests/ no conflict of interest

Funding: The study was self- funded

Authors' contributions: The study was carried out by Hannington Ngabirano under the supervision of Dr. Grace Birungi. Ngabirano wrote the draft manuscript which was revised by Dr. Birungi

Acknowledgements: Mbararara University of Science and Technology and Kabale University are acknowledged for provision of study space

\section{References}

1. Tilman D, Balzer C, Hill J, and Befort BL, 2011. Global food demand and the sustainable intensification of agriculture, vol. 108; no. 50: p. 20260-20264 (October 12, 2011).

2. Popp J., Pető K. and Nagy J., 2013. Pesticide productivity and food security. A review; vol. 33: p. 243255 (October 17, 2012); doi: 1007/s13593-012-0105-x.

3. Maksymiv, I., 2015. Pesticides: Benefits and Hazards, of Vasyl Stefanyk Precarpathian National University, Vol. 2, No. 1, 71-77; doi: 10.15330/jpnu.2.1.71-77.

4. Gill, H.K. and Garg, H., 2014. Pesticides: Environmental Impacts and Management Strategies. doi: $10.5772 / 57399$.

5. Jallow, M. F.A., Awadh, D. G., Albaho, M.S., Devi, V.Y., and Thomas, B. M., 2017. Pesticide Knowledge and Safety Practices among Farm Workers in Kuwait: Results of a Survey. J. Environ. Res. Public Health, 2017, 14, 340; doi: 10.3390/ijerph14040340 (March 24, 2017).

6. Majeed, A., 2018. Application of Agrochemicals in Agriculture: Benefits, Risks and Responsibility of Stakeholders. Food Sci Toxicol. Vol.2, No. 1.1 (February 05, 2018).

7. Zanella, R., Prestes, O. D., Friggi, C.A., Martins, M. L., and Adaime, M. B., 2012. An Overview about Recent Advances in Sample Preparation Techniques for Pesticide Residues Analysis in Cereals and Feedstuffs: http://dx.doi.org/10.5772/46846. 
8. Munawar, A., and Hameed, S.W., 2013. Quantification of Pesticide Residues in Vegetables by Different Chromatographic Techniques; J. Chromatograph Separat Techniq, Vol. 4 (8): http://dx.doi.org/10.4172/2157-7064.1000200.

9. Tano, J., 2011. Identity, Physical and Chemical Properties of Pesticides, Pesticides in the Modern World - Trends in Pesticides Analysis, ISBN: 978-953-307-437-5, InTech, Available from:http://www.intechopen.com/books/pesticides-in-the-modern-world-trends-inpesticidesanalysis/identity-physical-and-chemical-properties-of-pesticides.

10. Ragini, K., 2015. Survey on Pesticide Use, Monitoring of Pesticide Residues and Decontamination Methods in Bhendi (Abelmoschus Esculentus L.) in Hyderabad. Krishikosh Institutional Repository

11. Grubben, G.J.H., and Denton, O.A., (eds), 2004. Plant resources of Tropical Africa 2. Vegetables. PROTA Foundation, Wageningen, NetherlandsiBakhuys hb- lishers, Leiden, Netherlands/ CTA, Wageningen, Netherlands. 668 pp. ISBN 90-5782-147-8 (book only).

12. Sinyangwe, D.M., Mbewe, B. and Sijumbila, G., 2016. Determination of dichlorvos residue levels in vegetables sold in Lusaka, Zambia. Pan African Medical journal; doi:10.11604/pamj.2016.23.113.8211 (March 16, 2016).

13. Smith, F.I. and Eyzaguirre, P., 2007. African Leafy Vegetables: Their Role in the World Health Organization's Global Fruit and Vegetables Initiative; Vol. 7 No. 3 (December 1, 2006).

14. JICA, 2016. Vegetable Farming Techniques Manual: Government of Nepal, Ministry of Agriculture Development, Regional Agriculture Directorate, Central Development Region District Agriculture Development Office, Gorkha.

15. Chow, 2016. Pesticide Residues in Vegetables- Centre for Food Safety

16. Schwinn, F.J., 1988. Importance, possibilities and limitations of chemical control now and in future an industry view

17. Özkara, A., Akyl, D. and Muhsin, K., 2016. Pesticides, Environmental Pollution, and Health. doi: 10.5772/63094 (June 16, 2016).

18. Fouche, C., Molinar, R., Canevari, M., Joshel, C., Mullen, B. and Weber, J., 2000. Pesticides for specialty crops. Division of Agriculture and Natural Resources, University of California, Oakland, CA, USA.

19. Fait, A., Iversen, B., Tiramani, M., Visentin, S., Maroni, M., and He, F., 2001. Preventing Health risks from the Use of Pesticides In agriculture.

20. Fenik, J., Tankiewicz, M., and Biziuk, M., 2011. Properties and determination of pesticides in fruits and vegetables. TrAC Trends in Analytical Chemistry, 30(6). doi:https://doi.org/10.1016/j.trac.2011.02.008.

21. Perez, I. C. J., Gooc, C. M., Cabili, J. R., Rico, M. J. P., Ebasan, M. S., Zaragoza, M J. G., Redondo, A F. S., Orbita, R. R., Lacuna, M. L. D. G., 2015. Pesticide use among farmers in Mindanao, Southern Philippines.

22. Ohayo - Mitoko, G.J.A., 1997. Occupational pesticide exposure among Kenyan agricultural workers: An epidemiological and public health perspectives; Dissertation, Wagenigen Agricultural University. 
23. Okello, J.J. and Swinton, S., 2011. International Food Safety Standards and the Use of Pesticides in Fresh Export Vegetable Production in Developing Countries: Implications for Farmer Health and the Environment.

24. Miah, S.J., Hoque, A., Paul, A. and Rahman, A., 2014. Unsafe Use of Pesticide and Its Impact on Health of Farmers: A Case Study in Burichong Upazila, Bangladesh. iosrjournals.org.

25. Oesterlund, A. H., Thomsen, J. F., Sekimpi, D. K., Maziina, J., Racheal, A., and Erik Jørs 2014. Pesticide knowledge, practice and attitude and how it affects the health of small-scale farmers in Uganda: a cross-sectional study: African Health Sciences; 14(2):420-433: org/10.4314/ahs.v14i2.19.

26. Braun, A., Jiggins, J., Röling, N., van den Berg, H., Snijders, P., 2006. A Global Survey and Review of Farmer Field School Experiences. Nairobi, Kenya: International Livestock Research Institute; 2006.

27. Van den Berg, H. and Jiggins, J., 2007. "Investing in Farmers--The Impacts of Farmer Field Schools in Relation to Integrated Pest Management," World Development, Elsevier, vol. 35(4), pages 663-686, April.

28. Clausen, A.S., Jørs, E., Atuhaire, A. and Thomsen J.F., 2017. Effect of Integrated Pest Management Training on Ugandan Small-Scale Farmers: Volume 11: 1-10; https://doi.org/10.1177\%2F1178630217703391.

29. Naidoo, S., London, L., Rother, H.A., Burdorf, A., Naidoo, R.N., and Kromhout, H., 2010. Pesticide safety training and practices in women working in small-scale agriculture in South Africa. Occup Environ Med.67:823-828. doi: 10.1136/oem.2010.055863.

30. Bon, H., Huat, J., Parrot, L., Sinzogan, A., Martin, T. et al. 2014. Pesticide risks from fruit and vegetable pest management by small farmers in sub-Saharan Africa. A review. Agronomy for Sustainable Development, Springer Verlag/EDP Sciences/INRA, 34 (4), pp.723-736. ff10.1007/s13593-014-02167ff. ffhal-01234836.

31. Ngowi, A.V.F., Mbise, T.J., Ijani, A.S.M., London, L., and Ajayi, O.C., 2007. Pesticides use by smallholder farmers in vegetable production in Northern Tanzania. A.V.F; Crop Protection 26(11):1617-1624.

32. Marčić, D., Perić, P., Milenković, S., 2011. Acaricides - Biological Profiles, Effects and Uses in Modern Crop Protection. In: Stoytcheva M, editor. Pesticides - Formulations, Effects, Fate [Internet]. Serbia: In Tech; 37- 62. Available: http://www.intechopen.com/book s/pesticides-formulationseffectsfate/acaricides-biological-profiles-effectsand-uses-in-modern-crop-protection.

33. Nonga, H.E., Mdegela, R.H., Elisabeth, L., and Sandvik, M., 2011. Assessment of farming practices and uses of agrochemicals in Lake Manyara basin, Tanzania. J Agric Res; 6(10):2216-30. (May 18, 2011); DOI: 10.5897/AJAR11.271.

34. World Health Organizationand International Programme on Chemical Safety (WHO and IPCS) 2010. The WHO recommended classification of pesticides by hazard and guidelines to classification 2009. World Health Organization. https://apps.who.int/iris/handle/10665/44271. Link address: https://apps.who.int/iris/bitstream/handle/10665/44271/9789241547963_eng.pdf? sequence $=1$ \&isAllowed $=\mathrm{y}$. 
35. Knight, A.L. and Norton, G.W., 1989. Economics of agricultural pesticides resistance in arthropods, Annual Review of Entomology, vol. 34: 293-313.

https://doi.org/10.1146/annurev.en.34.010189.001453.

36. Vidogbena, F., Adegbidi, A., Tossou, R., et al. Control of vegetable pests in Benin- farmers' preferences for eco-friendly nets as an alternative to insecticides. J Environ Manage. 147:95-107

37. Yassin, M.M., Abu Mourad, T.A., and Safi, J.M., 2002. Knowledge, attitude, practice, and toxicity symptoms associated with pesticide use among farm workers in the Gaza Strip. Occup Environ Med. 59:387-393. doi:1136/oem.59.6.387

38. Maumbe, B. M. and Swinton, S.M., 2003. "Hidden health costs of pesticide use in Zimbabwe's smallholder cotton growers," Social Science \& Medicine, Elsevier, vol. 57(9), pages 1559-1571, November.

39. Jors, E., Morant, R.C., Aguilar, G.C., Huici, O., Lander, F., Baelum, J., and Konradsen, F., 2006. Occupational pesticide intoxications among farmers in Bolivia: a cross-sectional study. Environ Health, 5:10;doi: 1186/1476-069X-5-10.

40. Magauzi, R., Mabaera, B., Rusakaniko, S., et al., Health effects of agrochemicals among farm workers in commercial farms of Kwekwe district, Zimbabwe. Pan Afr Med J. 9:26.

41. Mushobozi, W.L., 2010. Good Agricultural Practices (GAP) on horticultural production for extension staff in Tanzania: Training Manual. FAO GAP Work Pap Ser [Internet]; 13:101-10. Available: http://www.fao.org/docrep/013/i1 645e/i1645e00.pdf

42. Mununa, F., Mkenda, J., Sikay, M., 2014. Post registration surveillance of pesticides: Towards Best Practices of Pesticide Management (BPPM) for environmental and human health protection in Tanzania. African Newsl [Internet]; 24(2):2. https://core.ac.uk/download/pdf/77101553.pdf

43. Mdegela, R.H., Mosha, R.D., Ngowi, H.A., and Nonga, H., 2013. Environmental and health impact associated with usage of agrochemicals in mindu dam catchment area, Morogoro, Tanzania. J Open Univ Tanzania: vol. 15 No 1.

44. Mhauka, A.B., 2014. Assessment of pesticide exposure pathways on humans in Mang'ola ward, Karatu District-ArBajwa, Tanzania. [Morogoro]: Sokoine University of Agriculture.

45. Mahugija, J.A.M., Khamis, F.A., and Lugwisha, E.H.J., 2017. Determination of levels of organochlorine, organophosphorus, and pyrethroid pesticide residues in vegetables from markets in Dar es Salaam by GC-MS. Int J Anal Chem [Internet]. 1-9. Available: file:///C:/Users/Admin/Downloads /4676724.pdf. doi:1155/2017/4676724.

46. Ogwu, M.C., Osawaru, M.E., Aiwansoba, R.O. and Iroh, R.N., 2016. Status and Prospects of Vegetables in Africa.

47. Chweya, J.A. and Eyzaguirre, P.B., (Eds), 1999. The Biodiversity of Traditional Leafy Vegetables. International Plant Genetic Resources Institute, Rome, Italy.

48. Joosten, F., Dijkxhoorn, Y., Sertse, Y. and Ruben, R., 2015. How does the Fruit and Vegetable Sector contribute to Food and Nutrition Security? Wageningen, LEI Wageningen UR (University and Research centre), LEI Nota 2015-076. 58 pp.; 4 fig.; 7 tab.; 52 ref. 
49. Chemonges,, 2018. Pesticides Residues in Soil and Mountain Gorilla Food Plants in and around Bwindi Impenetrable National Park.

50. McKinney, P., 2009. Uganda - WFP Remote Access Secure Services - World Food Programme (2009) https://documents.wfp.org/stellent/groups/public/documents/ena/wfp202495.pdf?iframe

51. Ministry of Trade, Industry and Cooperatives, 2016. Kabale District Economic Profile. Retrieved from:http://mtic.go.ug/2016/index.php?/The-Project/kabale-district-economic-profile accessed on 07/10/2019.

52. Carswell, G., 2002.Farmers and fallowing: agricultural change in Kigezi District, Uganda. The Geographical Journal, Vol. 168, No. 2, pp. 130-140.

53. Langan, C., and Farmer, J., 2014. Profile of Kabale District, Uganda https://drfarmerjen.files.wordpress.com/2017/09/kabale-district-profile-june-2014.pdf

54. Jamali, A.A., Solangi, A.R., Memon, N., and Nizamani, S.M., 2014. Current scenario of pesticide practices among farmers for vegetable production: A case study in Lower Sindh, Pakistan. International Journal of Development and Sustainability ISSN: 2168-8662 - www.isdsnet.com/ijds Volume 3(3): Pages 493-504 ISDS Article ID: IJDS13031403.

55. Pesticide Retailer Course, 2017. Trainer manual: Brussels at: https://croplife.org/wpcontent/uploads/2017/05/Pesticide-Retailer-Course_VApril2017.pdf

56. Okonya, J. S., and Kroschel, J., 2015. A Cross-Sectional Study of Pesticide Use and Knowledge of Smallholder Potato Farmers in Uganda.

57. Kumar, S., Sharma, A.K., Rawat, S.S., Jain, D.K. and Ghosh, S., 2013. Use of pesticides in agriculture and livestock animals and its impact on environment of India. Asian J. Environ. Sci., 8(1): 51-57.

58. Jeyanthi, H., and Kombairaju, S., 2005. Pesticide use in vegetable crops: frequency, intensity and determinant factors in Oddanchatram block of Dindigul District of Tamil Nadu, India. Agricultural Economics Research Review. Vol.18, 209-221.

59. Kabunga, N., Ghosh, S., and Griffiths, J.K., 2014. Can Smallholder Fruit and Vegetable Production Systems Improve Household Food Security and Nutritional Status of Women? Evidence from Rural Uganda.

60. Bindra, O.S., and Kalra, R.L., 1971. A review of work done in India on pesticide residues, Presented at Symposium on Progress and Problems in Pesticide Residue Analysis, Ludhiana. Nov. 18-19, 1991: 144.

61. Shukla, O.P., Omkar, and Kulshretha, A.K.,1998. Pesticides, man and Biosphere: APH Publishing cooperation.

62. Nalwanga, E., and Ssempebwa, J.C., 2011. Knowledge and practices of in-home pesticide use: a community survey in Uganda. J Environ Public Health. 230894, doi:1155/2011/230894.

63. Pedersen, B., Ssemugabo, C., Nabankema, V., and Jørs, E., 2017. Characteristics of Pesticide Poisoning in Rural and Urban Settings in Uganda;doi:10.1177/1178630217713015. 
64. Salameh, P.R., Baldi, I., Brochard, P., and Abi, S.B., 2004. Pesticides in Lebanon: a knowledge, attitude, and practice study. Environ Res, 94:1-6; doi:1016/s0013-9351(03)00092-6.

65. Abate, T., Van, H.A., and Ampofo, J.K., 2000. Pest management strategies in traditional agriculture: an African perspective. Annu Rev Entomol, 45; doi:1146/annurev.ento.45.1.631.

66. Macfarlane, E., Chapman, A., Benke, G., Meaklim, J., Sim, M., and McNeil, J., 2008. Training and other predictors of personal protective equipment use in Australian grain farmers using pesticides. Occup Environ Med, 65; doi:1136/oem.2007.034843.

67. Sam, K.G., Andrade H.H., Pradhan L., Pradhan A., Sones S.J., Rao P.G., and Sudhakar C., 2008. Effectiveness of an educational program to promote pesticide safety among pesticide handlers of South India. Int Arch Occup Environ Health, 81.doi:1007/s00420-007-0263-3.

68. Williamson, S., Ball, A., and Pretty J., 2008. Trends in pesticide use and drivers for safer pest management in four African countries. Crop Protection 27(10):1327-1334. doi:1016/j.cropro.2008.04.006.

69. Kumar, Surender and Yadav, P.R., 1998. Insect pest population fluctuation on early season cauliflower crop under Haryana agro-climatic conditions, Indian Journal of Plant Protection, 26(2): 145-148.

70. Aiswarya, V.A., Bhosle, B.B. and Bhede, B.V., (2018). Population Dynamics of Major Lepidopteran Insect Pests of Cabbage. Int.J.Curr.Microbiol.App.Sci. Special Issue-6: 236-239.

71. Uganda Bureau of Statistics 2016, The National Population and Housing Census 2014 - Main Report, Kampala, Uganda. https://www.ubos.org/wpcontent/uploads/publications/03_20182014_National_Census_Main_Report.pdf

72. Krejcie, R.V., and Morgan, D.W., 1970. Determining Sample Size for Research Activities. Educational and Psychological Measurement.

73. Carswell, G., 2003. Food Crops as Cash Crops: The Case of Colonial Kigezi, Uganda; Journal of Agrarian Change, Vol. 3 No. 4, pp 521-551.

74. Uganda Farmers Guide, 2019. Production Level Farmers Groups in Kigezi Sub-Region of Uganda.

75. Grewal, A. S., Singla, A., Kamboj, P., and Dua, J. S., 2017. Pesticide Residues in Food Grains, Vegetables and Fruits: A Hazard to Human Health. doi:15436/2575-808X.17.1355.

76. Baral, K., Roy, B.C., Rahim, K.M.B., Chatterjee, H., Mondal, P., Mondal, D., and Ghosh, D., 2006. Socioeconomic Parameters of Pesticide Use and Assessment of Impact of an IPM Strategy for the Control of Eggplant Fruit and Shoot Borer in West Bengal, India.

77. Moshi, A.P., and Matoju, I., 2017. The status of research on and application of biopesticides in Tanzania. Review. Crop Prot [Internet]; 92:16-28. Available: http://dx.doi.org/10.1016/j.cropro. 2016.10.008.

78. Ngowi, A., Mrema, E., and Kishinhi, S., 2016. Pesticide Health and Safety Challenges Facing Informal Sector Workers. NEW Solut A J Environ Occup Heal Policy [Internet]; 26(2):220-40. Available: http://journals.sagepub.com/doi/1 0.1177/1048291116650262. 
79. Lekei, E.E., Ngowi, A.V., and London, L., 2014. Farmers' knowledge, practices and injuries associated with pesticide exposure in rural farming villages in Tanzania. BMC Public Health [Internet];14(1):389.http://www.pubmedcentral.nih.gov/articlerender.fcgi?artid=3999359\&tool=p mcentrez\&rendertype $=$ abstract.

80. Manyilizu, W.B, Mdegela, R.H., Kazwala, R., Muller, M., Lyche, L.J., et al., 2015. Self-reported Health Effects among Short and Long-term Pesticide Sprayers in Arusha, Northern Tanzania: A cross Sectional Study. Occup Med Health Aff 3:223. doi: 10.4172/2329-6879.1000223.

81. Davis, R.F, Harris, G.H, Roberts, P.M and MacDonald G.E., 2009. Designing research and demonstration tests for farmers' fields.

82. Mdegela, R.H., Mosha, R.D., Ngowi, H.A., and Nonga, H., 2013. Environmental and health impact associated with usage of agrochemicals in mindu dam catchment area, Morogoro, Tanzania. $J$ Open Univ Tanzania: vol. 15 No 1.

\section{Figures}
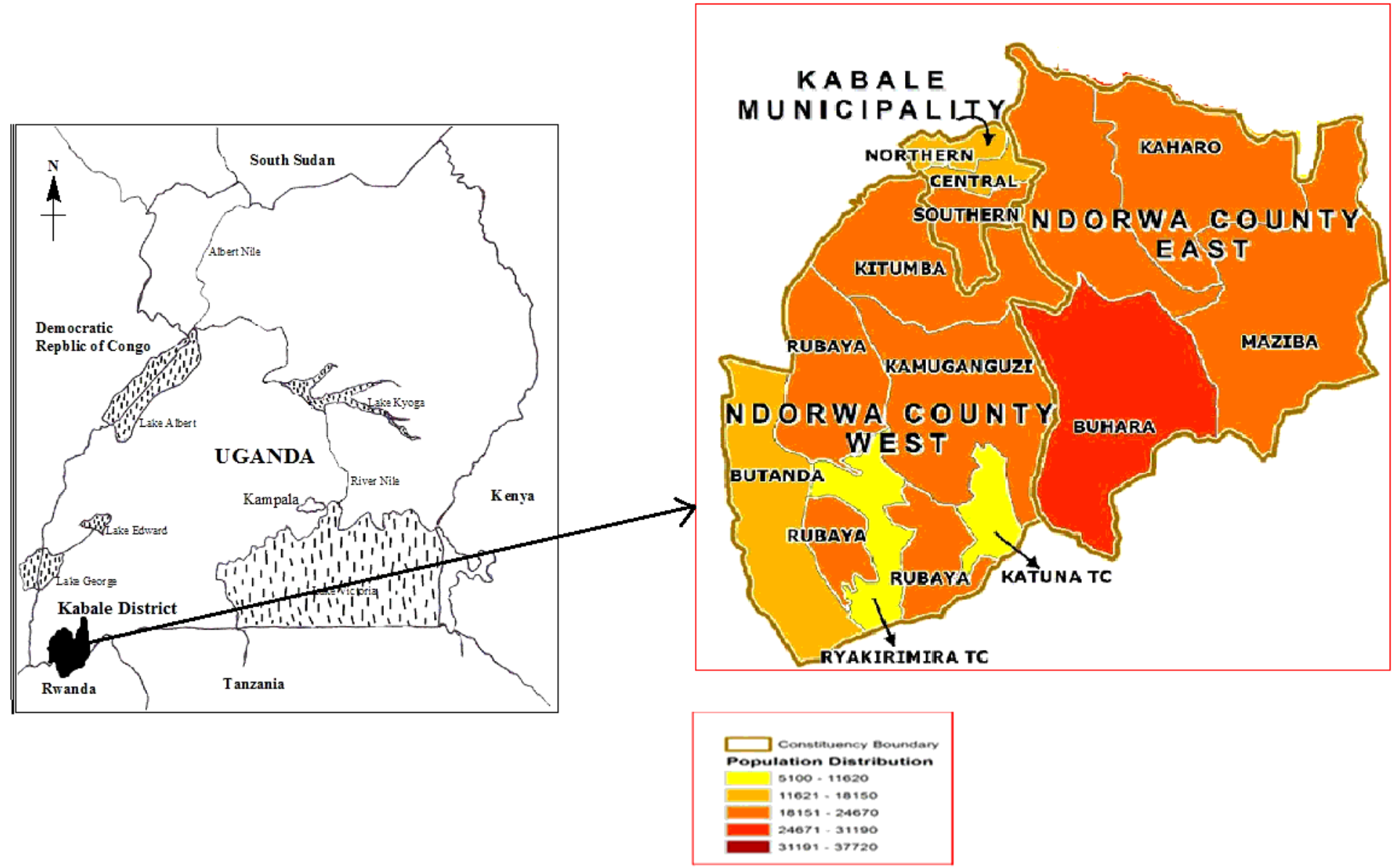

\section{Figure 1}

